\title{
ANCIENT GREEK HYDROMYTHS ABOUT THE SUBMARINE TRANSPORT OF TERRESTRIAL FRESH WATER THROUGH SEABEDS OFFSHORE OF KARSTIC REGIONS
}

\author{
STAROGRŠKI MITI O POVRŠINSKIH SLADKOVODNIH TOKOVIH \\ S KRASA, KI PONIKAJO V MORSKE PLASTI DALEČ \\ OD OBALE
}

\author{
Cindy CLENDENON ${ }^{1}$
}

\begin{abstract}
UDC 556.3:398.22

Cindy Clendenon: Ancient Greek Hydromyths About the Submarine Transport of Terrestrial Fresh Water Through Seabeds Offshore of Karstic Regions

This study examined the relationship between ancient Greek texts and the physical possibility of focused, distal flow of terrestrial fresh water through the seabed, particularly offshore of karstic coasts. The four ancient texts which were analyzed describe powerful discharges from submarine springs in the eastern Black Sea; the local transport of groundwater through the bed of Turkey's Bay of Miletus; alleged subterranean-submarine connections between coastal western Turkey and the Greek northeast Peloponnese; and alleged connections between the coastal western Peloponnese and southeastern coastal Sicily. The plausibility or implausibility of these legends was assessed in the context of modern reports indicating that seabed pathways can transport continental fresh water up to $60 \mathrm{~km}$ offshore. Other reports identify fresh water in the seabed as far as $160 \mathrm{~km}$ offshore, presumably due to marine-induced forces. These documented cases validated ancient claims of nearshore groundwater transport and legitimized transoceanic claims as mythologized extrapolations of local karstic hydrogeology. As submarine fresh groundwater becomes increasingly important in understanding material transport and in identifying potentially exploitable coastal water supplies, ancient stories from past civilizations may give clues to offshore sites meriting further exploration.

Keywords: submarine groundwater discharge, submarine karst springs, coastal karst aquifers, hydromythology, geomythology, history of karstology.
\end{abstract}

Izvleček

UDK 556.3:398.22

Cindy Clendenon: Starogrški miti o površinskih sladkovodnih tokovih s krasa, ki ponikajo $v$ morske plasti daleč od obale

Prispevek podrobneje razpravlja o odnosih med starogrškimi besedili in fizičnimi možnostmi kraških sladkovodnih tokov v morskih plasteh daleč od kraških obal. Štiri preučena besedila opisujejo močne podmorske izvire v vzhodnem delu Črnega morja, lokalni pretok podtalnice skozi plasti Mileškega zaliva v Turčiji, domnevne podzemeljsko-podmorske zveze med zahodno turško obalo in grškim severovzhodnim Peloponezom in domnevne zveze med obalo zahodnega Peloponeza in jugovzhodno obalo Sicilije. Verjetnost oziroma neverjetnost teh legend je bila ocenjena $\mathrm{z}$ vidika sodobnih poročil o pojavu celinske sladke vode $\mathrm{v}$ podmorskih plasteh do $60 \mathrm{~km}$ od obale. Druga poročila ugotavljajo sladko vodo celo do $160 \mathrm{~km}$ od obale, verjetno v zvezi s silami, ki jih povzroča morje. Navedeni primeri potrjujejo antične trditve o obalnem pretakanju podzemeljske vode in kažejo na legende, ki na podlagi lokalnega poznavanja kraške hidrologije razlagajo tudi prekomorske povezave. Ker postajajo podmorski sladkovodni izvir vedno bolj pomembni za poznavanje vodnih zvez in nakazujejo možno izrabo obalnih voda za oskrbo $\mathrm{z}$ vodo, lahko nudijo stare zgodbe nekdanjih civilizacij ključ do morskih predelov, ki bi zaslužili podrobnejše raziskave.

Ključne besede: sladkovodni podmorski izviri, vrulje, obalni kraški vodonosnik, miti o vodah, miti o geomorfoloških pojavih, zgodovina krasoslovja.

\footnotetext{
${ }^{1}$ Michigan Dept. of Environmental Quality, c/o Fineline Science Press, P.O. Box 10014, Lansing, Michigan 48901 USA, e-mail: c2editor@bloombb.com.
}

Received/Prejeto: 08.09.2009 


\section{INTRODUCTION}

The ancient Greeks were keen observers of their karstic environments, as evidenced by reliable accounts found in travelogues and myths set in the Greek mainland and in areas of ancient Greek settlement that contained significant karstlands: namely, southern peninsular Italy and Sicily; the eastern Adriatic; the Black Sea; western and southern Turkey; Cyrenaica (northeast Libya); and the Levantine coast (eastern Mediterranean). Like other ancient peoples living on karst, the Greeks witnessed karstic phenomena in their everyday lives. Although their observations of water movement sometimes were overlaid by tales of divinity, morality, and the human situation, the fundamental principles of karst hydrology are clearly evident in their written texts.
The study of karstic structures as depicted in ancient myth could be considered a subspecialty of geomythology, which is a fledgling scientific discipline first defined by Vitaliano $(1968,1973)$. But the study of karst waters and myth is better identified as hydromythology, which encompasses fantastic tales as well as scientifically plausible concepts about water, especially as articulated by ancient, prescientific cultures (Clendenon 2009a). This paper is a companion article to Clendenon (2009b), and further examines ancient Greek hydromyths in the context of karst hydrogeology.

\section{FOUR ANCIENT LEGENDS OF OFFSHORE TRANSPORT OF FRESH WATER THROUGH THE SEABED}

Because the ancient Greeks witnessed many sinkholes, ponors, caves, and other natural orifices in the rocky ground, they envisioned a vast subterranean UnderEarth penetrated by networks of caverns and tunnels containing water and fire. By integrating their real-life observations of karstic waters with their speculative visions of a subterranean Underworld, the Greeks rationally concluded that interconnected conduits exist under the ground and under the sea, even at long distances. Consequently, stories of seabed travels were not unusual among the ancient Greeks. Four examples illustrate the fundamental plausibility of these claims in the context of coastal karst hydrogeology.

\section{(1) EASTERN BLACK SEA (ABKHAZIA)}

In his treatise Meteorology (c. $350 \mathrm{BC}$ ), the Greek philosopher Aristotle mentions the frequency with which karstic streams in Greece sink underground and travel short distances to reach the sea (1.13). He contrasts these localized phenomena with a mid-scale occurrence in the Western Caucasus. Aristotle writes that at the foot of the Caucasus, many large rivers empty into a huge lake with no surface outlet. The lake waters sink underground and then resurge as three voluminous submarine springs in the eastern Black Sea. At an immeasurably deep place in the sea known as "the deeps of Pontus," about $58 \mathrm{~km}$ offshore, three fresh-water springs bubble up over a large area.

Aristotle identifies the place of the resurgence as being "off the land of the Coraxi." The ancient River Corax probably is the River Bzyb of present-day Abkhazia. This mountain river, like several others, flows through narrow, steep canyons and retains its fast flow as it approaches the Black Sea. The Bzyb watershed occurs amidst a welldeveloped limestone karst region where many rivers are lost in limestone cavities and then resurface again in powerful form (Bogutskaya 2009).

The Bzyb valley borders the karstic Bzybsky Massif, whose west slopes contain the Mchishta River cavespring, the largest in the Caucasus. On the other side of the Bzyb valley is the Arabika Massif of the Gagra Range, which is a well-studied karstic region with the world's deepest cave (Krubera-Voronja Cave) and hydrologic connections between the massif and resurgences along the Black Sea coast (Klimchouk \& Kasjan 2004). Studies in the Gagra district of Abkhazia have suggested the existence of a deep karst system with vigorous groundwater circulation. In the coastal Black Sea near the Arabika Massif, submarine springs discharge from depths ranging from a few meters to $400 \mathrm{~m}$ b.s.l. (Klimchouk 2006). In the coastal sea near the mouth of the River Zhovekvara, a huge submarine depression with dimensions of 5 by $9 \mathrm{~km}$ is a focus of submarine discharge. In the northern Black Sea, submarine groundwater discharge has been well studied along the southern coast of Crimea (Kondratev et al. 1999).

In light of these facts, Aristotle's claim of three ancient submarine springs $58 \mathrm{~km}$ offshore in the Black Sea seems hydrologically plausible. The copious flows from the Caucasus highlands could have provided enough 
pressure head to drive karst groundwater far out into the seabed. Speculatively, Aristotle's identification of "the deeps" could have referred to an area in the Black Sea where the seabed contained a deep fissure or possibly a large solutional collapse feature from which terrestrially derived fresh groundwater once could have discharged in large quantities. More than two millennia of environmental changes could have masked any evidence of this ancient feature.

\section{(2) BAY OF MILETUS (TURKEY)}

In a plausible account summarized by Clendenon (2009c), the ancient Greek geographer Pausanias (c. 175 $\mathrm{AD}$ ) mentioned that an unnamed river of western coastal Turkey had its source on Mount Mycale (Pausanias 5.7.5). This low mountain possesses karstic features and in classical times formed a promontory surrounded on three sides by the Aegean Sea. According to Pausanias, the river's mountainous headwaters sank underground and traveled through the seabed of the bay before rising on the opposite shore (5.7.5).

Pausanias probably was referring to the Bay of $\mathrm{Mi}$ letus, a deep embayment which once separated the Greek cities of Priene and Miletus, but eventually was filled by sediment deposited by the River Meander (today's Büyük Menderes). Today part of this region is protected via the Dilek Peninsula National Park and the Büyük Menderes Delta National Park.

The ancient tale told by Pausanias clearly is plausible in terms of karst hydrogeology. Given Mount Mycale's elevation and proximity to the shoreline, the continental hydraulic head could have been sufficient to drive the groundwater approximately $10 \mathrm{~km}$ through a hydrologically connected, unimpeded pathway in the seabed of the bay. Speculatively, the unnamed ancient coastal river could have flowed from its onshore channel through a contiguous paleo-channel that had been submerged by the sea after the Pleistocene glacial maxima. In the eastern Adriatic, for example, canyons of certain paleo-rivers still are recognizable in sea waters between islands and mainlands, even to water depths of $100 \mathrm{~m}$ (Surić 2002).

\section{(3) RIVER MEANDER (TURKEY) AND RIVER ASOPUS (GREECE)}

In a legendary tale of submarine transport of terrestrial fresh water on a vast scale, the Turkish River Meander (Büyük Menderes) was said to empty into the Aegean Sea, travel through the Aegean seabed, and resurface $390 \mathrm{~km}$ to the west as the Greek Arcadian River Asopus near Sicyon in the northeast Peloponnese (Pausanias 2.5.3). According to the ancient Greek geographer Strabo
(6.2.271), this legend of the undersea journey had been articulated as early as the sixth century BC by the Greek lyric poet Ibycus, who said that the headwaters of the Sicyonian Asopus arose in Phrygia, an ancient kingdom in west-central Turkey. In the fifth century BC, the poet Bacchylides likewise drew from this legend.

Pausanias provided mythologized evidence to support this claim (2.7.9). The wooden flutes of a satyr were said to float in the River Meander, divert underground with its sinking flow (probably through a streambed ponor near the river mouth), travel through the Aegean seabed with the submarine groundwater flow, and ultimately resurge with the terrestrial springflows of the $\mathrm{Si}$ cyonian River Asopus in the Greek Peloponnese.

Although the mythical aspect of the satyr is fictitious, the portion of Pausanias's account about floating objects that are suctioned underground is an accurate depiction of karstic waters. The large Meander watershed does indeed include karstic terranes, including today's UNESCO World Heritage Site of Hierapolis-Pamukkale, which is located in a tributary basin. But the portion of the story about a $390-\mathrm{km}$ seabed journey is an imaginative exaggeration. Even Pausanias recognized that the actual source of the Sicyonian Greek River Asopus is on a local Phliasian mountain (2.5.2), an observation reiterated by Leake (1830).

\section{(4) RIVER ALPHEUS (GREECE) AND SPRING OF ARETHUSA (SICILY)}

Perhaps the best known and most geographically expansive tale of submarine fresh water is the story of the Arcadian spring nymph Arethusa and the Peloponnesian river god Alpheus. This Greek myth may have originated as early as the eighth century BC (Bilić 2008).

The River Alpheus rises in Greece's northern Taygetus Mountains and travels generally northwest into Elis, passing the ruins of Olympia before ultimately emptying into the Ionian Sea. In myth, Arethusa once was a human-like nymph living in Peloponnesian Arcadia, but she ultimately relocated and became a karstic spring in Syracuse, Sicily. She is not to be confused with the ancient fountain of Arethusa in Chalcis (Euboea), nor with other ancient pools or springs also named Arethusa. The Syracusean islet of Ortygia is not to be confused with the Ortygia near Chalcis, nor with other Ortygias associated with ancient Aetolia, Delos, and Ephesus.

In the Greek myth of Alpheus and Arethusa, Arethusa fled across the Peloponnesian landscapes to escape Alpheus's amorous advances. She became so nervous in the foggy mist that she transformed into water and disappeared down into the Earth near the coast of Elis. Once underground, watery Arethusa took a submarine 
journey through the bed of the Ionian Sea. Eventually she resurfaced as a karstic fresh-water spring on Ortygia in Syracuse, Sicily. Because the River Alpheus had followed Arethusa down into the Earth, he traveled with her through the seabed and resurfaced with her on Ortygia. Like Arethusa, Alpheus never mixed with the sea water, and his waters remained fresh.

The straight-line distance of this transoceanic journey was about $550 \mathrm{~km}$, which would have been nearly a 3-day ancient sailing voyage under good conditions (Bilić 2008). Bilić speculates that the myth of Alpheus-
Arethusa emerged as a description of latitude-sailing linked to the historical association of coastal Elis with sea crossings to Italy and Sicily. Geographically expansive political-colonial affiliations also could have influenced the scope of this Greek myth. But as described below, Strabo and Pausanias said nothing about celestial navigation (Pausanias 5.7.2-3 and 8.54.2-3; Strabo 6.2.271). Instead, they referred to the karstic features of the Alpheus watershed, which strongly suggests a karstic influence on the myth's origin.

\section{THE ALPHEUS-ARETHUSA MYTH IN A HYDROGEOLOGIC CONTEXT}

Pausanias saw no reason to disbelieve the possibility that the River Alpheus passed through the seabed and mingled his waters with Arethusa before resurfacing on the Sicilian island of Ortygia (5.7.3). Pausanias's religious basis of belief was the oracle of Apollo at Delphi, which Greeks viewed as among the most reliable of the oracles. Pausanias's rational basis of belief was his knowledge of the naturally peculiar behavior of karstic rivers. Of the River Alpheus, Pausanias accurately stated, "It often disappears beneath the Earth, to reappear again" (8.54.2). One of its sinking points was near Cyllene, the ancient port of Elis.

Like Pausanias, Strabo had heard legendary stories of Alpheus's long transit through the seabed. But unlike Pausanias, Strabo demonstrated his Stoic philosophy by remaining skeptical of the stories that he recounted. Strabo disagreed even as he cited the proto-scientific evidence which myth-believers adduced to support the myth: namely, that the blood of sacrificial oxen and small objects that were introduced into the River Alpheus at Olympia were said to reappear far away at the Ortygian fountain in Sicily. These anecdotes of action and observation are the equivalent of ancient watertracing tests.

\section{SKEPTICAL BELIEVERS}

Strabo was aware of several karstic rivers that sank underground and later reappeared after fairly short distances in terrestrial settings. He also knew about fantastic tales of far-ranging underground connections of rivers (6.2.271). Strabo admitted that if the River Alpheus sank into a ponor before joining the sea, there would be some plausibility in the view that the river extended underground from Olympia to Syracuse. But Strabo states that he personally did not observe any visible whirlpool from a draining ponor at the mouth of the River Alpheus. Furthermore, Strabo could not bring himself to accept the possibility that terrestrial fresh groundwater could travel a long distance through the seabed without eventually becoming mixed with saltwater. In today's terms, Strabo believed that a confined aquifer in the seabed would necessarily contain one or more breaches that would allow saltwater intrusion. He concluded that the alleged phenomenon was "absolutely impossible" and "utterly mythical" (6.2.271).

The late Dorothy B. Vitaliano (1916-2008), who was a volcanologist and technical translator for the U.S. Geological Survey, is the putative founder of geomythology. But despite her open-mindedness to the fantastic myth of Lost Atlantis, Vitaliano dismissed as impossible the much less fantastic Arethusa myth. Echoing Strabo, Vitaliano scoffed that the legend of Arethusa is purely mythical. "Nothing in this tale, of course, has the slightest basis in fact," Vitaliano declared in her 1973 book.

Vitaliano presented no argument against the myth of Arethusa that is specific to conditions in the Alpheus watershed nor along the coasts of Elis or southeast Sicily. Vitaliano, like Strabo, did not entertain the possibility that pits and ponors, which are abundant in the Alpheus's upper watershed, also could have existed in its lower watershed, including the river segments in proximity to the delta. An observer viewing the land of the ancient river delta in isolation from the larger catchment would have been unaware of the potential subterranean diversion of part of the river's surface flow. The subterranean component could have passed seaward through one or more underground karstic conduits extending into the coastal seabed, just as the myth indicates. 


\section{HYDROGEOLOGIC CONSIDERATIONS OF THE GREEK RIVER ALPHEUS}

A close reading of the ancient myth of Arethusa suggests hydrogeologic components. Arethusa's transformation from a nymph to water which subsequently sank into the ground probably represented the infiltration of rainfall and surface runoff into the porous soil and karstic subsurface. Her travel through the Underworld suggested that she moved laterally through a subterranean pathway that surely was karstic, owing to the predominance of karstic terranes in the Alpheus watershed. Alpheus, when he diverted his river waters underground in an attempt to mingle his groundwater with Arethusa's groundwater, probably represented one or more sinking segments of the River Alpheus and/or one or more of its lower tributaries.

When these aspects of stream sinkings and subterranean conduits are combined, it would seem that the ancient story was describing more than one onshore hydrologic unit that contributed to a single karstic conduit or fracture zone extending into the seabed. If this was the case, the seaward flow of fresh water could have been substantial.

Modern claims involving the same geographical vicinity suggest that there may have been a hydrogeological basis for the ancient myth. At least since the seventeenth century, a hydrologic connection is believed to have existed between the Peloponnesian mainland and one of the Strophades Islands. These islands are about $45 \mathrm{~km}$ west of the Peloponnesian coast, generally west of the Kyparissia Gulf, southwest of the mouth of the River Alpheus, and about $43 \mathrm{~km}$ south of the island of Zacynthus.

The local claim of the Strophadic hydrologic connection was documented in 1674 by Pierre Perrault (1608-1680), a Parisian who is considered to be among the earliest quantitative hydrologists (Nace 1974; Fetter 2004). The anecdote documented by Perrault (1674) was cited many years later by Dominique Francois Jean Arago (1786-1854), a highly honored French scientist and writer. According to Arago (1835), monks inhabiting the Strophades Islands claimed that one of the springs originated on the Peloponnese mainland, and then flowed through the seabed before emerging on the island. The waters of this island spring were said to frequently contain objects that could have come only from the mainland. On one occasion, the spring fountain revealed a drinking cup fashioned from a gourd and adorned with silver.

Today the Strophades possess only one or two seasonal springs. A few wells obtain water at the contact between the calcarenites and marls (Fountoulis, personal communication). Although many parts of the Peloponnese and the island of Zacynthus are characterized by karstified carbonates, there is no evidence of limestones or generally carbonatic karstified rocks on the Strophades (Fountoulis, personal communication), which calls into question whether a karstic submarine conduit system once extended between the Strophades and the mainland. But because submarine groundwater transport can occur in unconsolidated substrates and bedrock seabeds encompassing nonkarstified and karstified rocks, the old tale of a submarine hydrogeologic connection between the Peloponnese mainland and the Strophades should not be entirely discounted.

According to the Hellenic Ministry for the Environment (2009), the Strophades, like Zacynthus, are believed to have emerged from the seafloor when a submarine plate was forced upward by seismotectonic forces. The major geological realignments in this region created many islets, reefs, and underwater shelves. Speculatively, a hydrogeologic connection once could have existed through fractures or perhaps through locally karstified conduits that ultimately were destroyed by prehistoricalhistorical earthquakes and buried by sedimentation.

\section{HYDROGEOLOGIC CONSIDERATIONS OF THE SICILIAN SPRING OF ARETHUSA}

Today, two bays of Syracuse, Sicily flank Ortygia, the site of Syracuse's initial settlement. The modern island-like peninsula of Ortygia projects southward into coastal waters, creating a large bay to the west, less than $2 \mathrm{~km}$ wide, which is indented by a main harbor about $500 \mathrm{~m}$ wide. A small harbor indents the bay east of Ortygia.

The modern spring of Arethusa is located at the seaside on the west shore of Ortygia, south of the main harbor (Crouch 1993, 1996). The present-day spring of Arethusa may not be identical to the ancient spring of Arethusa because the most ancient settlement on Ortygia is overlain by the Medieval and Baroque city, and the Hellenistic city has been transformed by modern urban development (Crouch 1993). The following discussion refers to the modern spring of Arethusa.

Crouch (1993) posits a karst origin for the Arethusa spring, other coastal and submarine springs of Syracuse, and the headsprings of the two rivers west of the main bay. The springs of Ortygia are recharged by meteoric water from the mainland north and west of Ortygia. The water-bearing karstified limestone of Syracuse, which is overlain by an impermeable layer of marl and conglomerate, slopes from the northwest down toward the bays and harbors, where it outcrops on Ortygia. During karst development, meteoric water seeped along the bedding planes and, under the hydraulic head afforded 
by the inland mountains and plateaus, pushed upward to eventually dissolve shafts in the rock. When the shafts pierced the seabed surface and land surface, fresh artesian springs would flow. This could explain why a line of fresh-water submarine springs once was visible in both bays flanking Ortygia (Crouch 1990). Crouch speculates that the cessation of most former springs may be due to plugging of the shafts, or a reduction in artesian pressure due to heavy urban groundwater usage in the modern city, or both. Historical earthquakes have caused minor intrusions of sea water into the Arethusa spring.

Kontar and Ozorovich (2006) identify submarine faults as additional conduits for submarine groundwater flow in coastal southeastern Sicily. In general, southeast Sicily contains karstified carbonates, and the Hyblean Plateau is an area of known submarine groundwater discharge.

\section{MODERN EXAMPLES OF SUBMARINE FRESH WATER}

About $80 \%$ of the major submarine springs in today's Mediterranean basin are in sea water up to $10 \mathrm{~m}$ in depth, and only a few are located at depths up to $50 \mathrm{~m}$ (LaMoreaux \& Tanner 2002). Most measurements of submarine groundwater discharge range from a few meters to a few kilometers offshore where discharges are easily found, large volumes are expected, and the seabed is relatively accessible; however, fresh submarine groundwater can emerge at various depths and distances offshore (Taniguchi et al. 2002).

For example, in Atlantic coastal North Carolina, marine geophysical evidence has suggested that terrestrial groundwater is transported to a zone of locally punctuated, high-flux submarine discharge situated $20 \mathrm{~km}$ offshore (Evans \& Lizarralde 2003). The ocean/groundwater exchange is associated with localized seafloor karstification and may be the result of offshore transport through, and release from, a confined carbonate unit extending offshore from a productive onshore aquifer.

In Atlantic coastal Florida, a submarine collapse sinkhole known as Red Snapper Sink is located $42 \mathrm{~km}$ offshore on the continental shelf (Spechler \& Wilson 1997). The floor of its structure is at least $147 \mathrm{~m} \mathrm{b.s.l.,}$ and there appears to be a hydrologic connection to the onshore Floridan carbonate aquifer system. However, scientific expeditions have not confirmed the claim by mariners that fresh springwater sometimes discharges from this seafloor sinkhole.

Closer to shore and west of Red Snapper Sink is Florida's Crescent Beach Spring, an artesian seabed spring located $4 \mathrm{~km}$ from the coast. The point of submarine groundwater discharge is a well-defined dissolution-collapse feature whose deepest point is $38 \mathrm{~m}$ b.s.l. (Swarzenski et al. 2001). The source water is the result of a complex, karst-induced mixing regime that includes younger and older groundwater.

In addition to evidence of fresh water flowing from the seabed as a point-source discharge, there is evidence from deep-sea drilling programs. For example, interstitial fluid studies on the continental shelf off the Atlantic coast of the southeastern United States revealed that substantial fresh water lies trapped in deep strata (Hathaway et al. 1979). One exploratory well drilled in limestone $250 \mathrm{~m}$ b.s.l. and $40 \mathrm{~km}$ offshore of Jacksonville, Florida produced a flow of fresh water with a hydrostatic head of $10 \mathrm{~m}$ a.s.l. This reasonably aligns with numerical modeling results for the northern Atlantic coastal margin, which anticipated fresh water extending $60 \mathrm{~km}$ offshore if the onshore hydraulic head was $6 \mathrm{~m}$ a.s.l. (Meisler et al. 1984). Hydrologic testing in an abandoned oil well $88 \mathrm{~km}$ offshore revealed fresh water as deep as $335 \mathrm{~m}$ b.s.l. (Johnston 1983). Submarine fresh water was estimated to be present as far as $100 \mathrm{~km}$ from the shore (Manheim 1967) and to a depth of approximately $900 \mathrm{~m}$ (Manheim \& Paull 1981).

A nineteenth-century anecdote of fresh water emerging far offshore is provided by Arago (1835), who reported that a copious upwelling of fresh water was observed in the Bay of Bengal by a passenger on a British ship that was $161 \mathrm{~km}$ from the nearest point of the neighboring coast of the Sunderbunds. The Sunderbunds (Sundarbans) is a vast area of swamps, mangrove forest, and jungles encompassing the lower Ganges delta and stretching for $260 \mathrm{~km}$ along the coast of the Bay of Bengal. The ship's location was $201 \mathrm{~km}$ from Bangladesh's primary seaport of Chittagong.

Although Arago did not provide details which would help identify the nature of the spring-vent in the seabed, the release of a large fresh-water plume from the seafloor presumably involved marine-induced forces, rather than simply the offshore head-driven transport from a productive onshore aquifer, as Arago suggested. A limited literature search revealed no scientific studies of submarine springs far offshore in the Bay of Bengal, but Basu et al. (2001) demonstrated substantial groundwater flux at the land-sea interface of the Ganges-Brahmaputra basin. Unknown is whether there might be any association between fresh groundwater discharge far offshore and the so-called "Swatch of No Ground," a continental 
shelf canyon in the northern Bay of Bengal that extends beyond the Ganges-Brahmaputra delta. The head of this well-studied submarine canyon incises about $30 \mathrm{~km}$ from the deltaic coast and continues seaward as a nearly linear trough for $160 \mathrm{~km}$, with submarine fan valleys and levees radiating hundreds of kilometers farther.

\section{COASTAL SALINE WATER MOVEMENT KNOWN TO ANCIENT GREEKS}

Because of the ever-present need for drinking water, the ancient Greeks were keenly interested in terrestrial and submarine discharge of fresh water, which is the focus of this paper. But a discussion of the offshore movement of coastal karstic groundwater would not be complete without brief mention of the reverse occurrence: namely, the inland movement of saline sea water through subterranean conduits.

Pausanias states that inland springs of sea water flow in unlikely places (8.10.4). For example, sea water arose on the Athenian acropolis, which was nearly $4 \mathrm{~km}$ inland from the city's seaport at Phalerum. In the city of Mylasa in southwest coastal Turkey, sea water emerged at the sanctuary of Zeus, which was situated about $15 \mathrm{~km}$ inland from the city's seaport. In a third example, Pausanias reports that sea water arose at the sanctuary of Poseidon near the ancient Arcadian city of Mantinea, which was about $13 \mathrm{~km}$ inland from the Gulf of Argos. In all these cases, it is possible that sea water intruded landward through either marine estavelles, fissures, or interconnected karstic conduits in submarine and subterranean carbonates. The intensity of marine influence is variable and depends on local factors such as geology, hydrologic interconnection, hydraulic gradient, tidal effect, and the interactions of fresh and salt water. In one modern example in the coastal karst of Croatia, sea water is known to travel inland for approximately $6 \mathrm{~km}$ (Surić 2002).

Pausanias reports that streams of sea water known as Rheiti followed a subterraean course from the famous Euripus, or Strait of Chalcis, southward about $46 \mathrm{~km}$ to Eleusis (1.38.1 and 2.24.6). Eleusis was an ancient coastal city on the Saronic Gulf northwest of Athens and opposite the island of Salamis. Aristotle likewise mentioned that in certain karstic regions of Euboea, the sea allegedly flowed in channels beneath the Earth's surface (Meteorology 2.8).

In modern times, Leake (1830) opined that the subterranean course of the Rheiti is imaginary, dismissing it as a fable of Athenian growth and inaccurately stating that the Athenians would not have been familiar with sinkholes in Attica. Leake ignored the fact that the areas of ancient Attica and Boeotia are flanked by the geologically, seismotectonically complex regions of the North-South Euboean Gulfs, the Gulf of Corinth, and the Saronic Gulf, all of which include karstified carbon- ates and fault systems (Higgins \& Higgins 1996). Sea water could have been visibly lost through shallow seabed swallow holes (sea ponors), and then visibly discharged elsewhere, just as Pausanias stated. Speculatively, perhaps the sea-water flow was influenced by the local geomorphological peculiarities at the Strait of Chalcis, which amplified the generally minor tidal effect to a locally significant level (Higgins \& Higgins 1996). This author further speculates whether the unpredictable tidal currents at the strait could be partially influenced by subterranean-submarine karstic interconnections.

At several locations in modern Greece, sea water has been seen flowing into sea ponors. Divers in the early 1960s reported movements of sea water into the fissures of the Vouliagmeni collapse structure south of Athens (Burdon 1965), which gives some validity to Pausanias's claim of sea water resurging at the Athenian acropolis. Lake Vouliagmeni is a fresh-water lake and submerged cave fed partly by underground currents seeping through the mass of Mount Hymettus. Also in the early 1960s, hydrogeologists reported that in Crete when the sea is calm, vortices could be seen offshore as sea water was suctioned down into two sea ponors near the mouth of the Almiros River (Burdon \& Papakis 1964). A seabed structure known as the Balli estavelle, located $500 \mathrm{~m}$ from the shoreline at a depth of $25 \mathrm{~m}$ b.s.l., was shown to swallow sea water during the dry season.

The best-known "disappearing sea" in Greece is on the Ionian island of Cephalonia. On the island's west coast near the modern-day capital city of Argostoli, sea water gushes down into small, deep ponors in the bed of the harbor. After the sea water disappears into subterranean channels, it travels underground northeastward across the entire island, passing under hills and mountains of the island's interior. About $15 \mathrm{~km}$ downgradient, portions of the swallowed waters emerge on the east coast at a small brackish lake and springs near Karavomilos, a coastal village northwest of the port city of Sami. Lists of scientific publications related to Cephalonia's karstic phenomena are provided by Zötl (1989) and Fleury et al. (2007). The ancient Greeks knew about the ArgostoliSami system, as evidenced in the myths of the nymph Melissani and shepherdess Melisanthe, whose names became synonymous with the modern-day tourist cave and its brackish subterranean lake. 


\section{ANCIENT MYTHS AND MODERN KARST HYDROGEOLOGY}

Ancient Greek stories about fresh terrestrial groundwater traveling through the beds of major seas become implausible only when the distances exceed a few tens of kilometers.

In this author's opinion, the transoceanic myths of Alpheus-Arethusa and Meander-Asopus were longdistance extrapolations of local karstic phenomena. The Greeks probably reasoned that if karstic streams could sink and resurge over distances of a few kilometers to a few tens of kilometers, then streams presumably could sink and resurge over long distances, regardless of whether the land is submerged by a sea.

In the early years of quantitative groundwater tracing, most scientists would have considered it implausible that surface water could divert underground into continental subterranean conduits and travel scores of kilometers before resurfacing. Today, the horizon of possibility has been expanded as water tracers in noncoastal regions have been shown to travel nearly $64 \mathrm{~km}$ (as measured in the Missouri Ozarks; Aley 1997) and $120 \mathrm{~km}$ (as measured in Turkey's Taurus Mountains; Bakalowicz, personal communication). The world's longest caves exceed $200 \mathrm{~km}$, including the Mammoth Cave-Flint Ridge System (USA), whose network of passages surveyed in 2006 totaled $591 \mathrm{~km}$. Although these examples of terrestrial and alpine karst systems are not analogous to coastal and submarine systems of the ancient Mediterranean, the measured distances help frame the context of the discussion.

Although the movement of fresh groundwater through a karstified seabed for more than a few tens of kilometers offshore may never be scientifically ascertained, seemingly imaginative legends of long-distance submarine groundwater transport may encourage hydrogeologists to reconsider the distance that potentially could be traversed by a well-confined aquifer in a submarine environment. As submarine fresh groundwater becomes increasingly important in understanding material transport and, in places, identifying potentially exploitable coastal water supplies, ancient tales from past civilizations may give clues to sites meriting further exploration.

\section{ACKNOWLEDGEMENTS}

The author gratefully acknowledges the scientists who provided valuable correspondence: Michel Bakalowicz (HydroSciences Montpellier, France); Jaye Cable (Louisiana State University, USA); Ioannis Fountoulis (National and Kapodistrian University of Athens, Greece);
Daniel Lizarralde (Woods Hole Oceanographic Institution, USA); George "Rip" Rapp (University of Minnesota, USA); and Peter Swarzenski (U.S. Geological Survey, USA).

\section{REFERENCES}

Aley, T., 1997: Groundwater tracing in the epikarst.- In: Beck, B.F. \& J.B. Stephenson (eds.) The Engineering Geology and Hydrogeology of Karst Terranes. Balkema, pp. 207-211, Rotterdam, Netherlands.

Arago, M., 1835: On springs, artesian wells, and spouting fountains.- The Edinburgh New Philosophical Journal, 18, 205-246.

Aristotle, c. 350 BC: Meteorology.- Webster, E.W. (transl.), 1984, Princeton University Press, Princeton, New Jersey. [Online] Available from: http://classics.mit. edu/Aristotle/meteorology.html [Accessed $7^{\text {th }}$ September 2009].
Basu, A.R., Jacobsen, S.B., Poreda, R.J., Dowling, C.B. \& P.K. Aggarwal, 2001: Large groundwater strontium flux to the oceans from the Bengal Basin and the marine strontium isotope record.- Science, 293, 1470-1473.

Bilić, T., 2008: The myth of Alpheus and Arethusa and open-sea voyages on the Mediterranean: stellar navigation in antiquity.- International Journal of Nautical Archaeology, 38, 116-132. 
Bogutskaya, N., 2009: Freshwater Ecoregions of the World, Region 433, Western Transcaucasia.- [Online] Available from: http://www.feow.org/ecoregion_details.php?eco=433 [Accessed 7th September 2009].

Burdon, D.J., 1965: Hydrogeology of some karstic areas of Greece.- In: International Hydrological Decade, International symposium on hydrology of fractured rocks, $7^{\text {th }}-14^{\text {th }}$ October 1965, Dubrovnik, Yugoslavia. UNESCO, Paper 11, 308-317, Paris, France.

Burdon, D.J. \& N. Papakis, 1964: Preliminary note on the hydrogeology of the Almiros Spring, Iraklion, Crete.- Institute of Geology and Subsurface Research, 9, 125-144.

Clendenon, C.J., 2009a: Hydromythology and the Ancient Greek World: an Earth Science Perspective Emphasizing Karst Hydrology.- Fineline Science Press, pp. 520, Lansing, Michigan.

Clendenon, C.J., 2009b: Karst hydrology in ancient myths from Arcadia and Argolis, Greece.- Acta Carsologica, 38, 1, 145-154.

Clendenon, C.J., 2009c: Ancient Greek geographer Pausanias as a qualitative karst hydrogeologist.- Ground Water, published online. Available from: http:// www3.interscience.wiley.com/journal/122598448/ abstract [Accessed 15 $5^{\text {th }}$ September 2009].

Crouch, D.P., 1990: Planning water management for an ancient Greek city.- In: International Association of Hydrological Sciences, Hydrological processes and water management in urban areas, Proceedings of the Duisberg symposium, 24 ${ }^{\text {th }}-29^{\text {th }}$ April 1988, Duisberg, Federal Republic of Germany. IAH, Publication 198, 271-277, The Hague, Netherlands.

Crouch, D.P., 1993: Water Management in Ancient Greek Cities.- Oxford University Press, pp. 400, New York.

Crouch, D.P., 1996: Environmental geology of ancient Greek cities.- Environmental Geology, 27, 233-245.

Evans, R.L. \& D. Lizarralde, 2003: Geophysical evidence for karst formation associated with offshore groundwater transport: an example from North Carolina.- Geochemistry, Geophysics, Geosystems, $4,8,1069,1-9$

Fetter, C.W., Jr., 2004: Hydrogeology: a short history, part 1.- Ground Water, 42, 5, 790-792.

Fleury, P., Bakalowicz, M. \& G. de Marsily, 2007: Submarine springs and coastal karst aquifers: a review.Journal of Hydrology, 339, 79-92.

Hathaway, J.C., Poag, C.W., Valentine, P.C., Miller, R.E., Schultz, D.M., Manheim, F.T., Kohout, F.A., Bothner, M.H. \& D.A. Sangrey, 1979: U.S. Geological Survey core drilling on the U.S. Atlantic Shelf.- Science, 206, 515-527.
Hellenic Ministry for the Environment, Physical Planning \& Public Works, 2009: Natura 2000 in Hellas, Site Name Nisoi Strofades, Site Code GR221003.[Online] Available from http://www.minenv. gr/1/12/121/12103/old2/new\%20backup/english_ all/e2210003.html [Accessed 7th September 2009].

Higgins, M.D. \& R.A. Higgins, 1996: A Geological Companion to Greece and the Aegean.- Cornell University Press, pp. 256, Ithaca, New York.

Johnston, R.H., 1983: The saltwater-freshwater interface in the Tertiary limestone aquifer, southeast Atlantic outer-continental shelf of the USA.- Journal of Hydrology, 61, 239-249.

Klimchouk, A.B., 2006: The deepest cave in the world in the Arabika Massif and the evolution of the Black Sea (in Russian).- Svet (Light), 2, 31, 33-36.

Klimchouk, A.B. \& Y. Kasjan, 2004: In a search for the route to 2000 meters depth: the deepest cave in the world in the Arabika Massif, Western Caucasus.Caves.com The Magazine, Issue 8, Dec 2003/Feb 2004, 16-24.

Kondratev, S.I., Dolotov, V.V., Moiseev, Y.G. \& Y.T. Shchetinin, 1999: Submarine springs of fresh water in the region from Cape Feolent to Cape Sarych.Physical Oceanography, 10, 3, 257-272.

Kontar, E.A. \& Y.R. Ozorovich, 2006: Geo-electromagnetic survey of the fresh/salt water interface in the coastal southeastern Sicily.- Continental Shelf Research, 26, 843-851.

LaMoreaux, P.E. \& J.T. Tanner (eds.), 2002: Springs and Bottled Waters of the World: Ancient History, Source, Occurrence, Quality and Use.- Springer-Verlag, pp. 315, New York.

Leake, W.M., 1830: Travels in the Morea (3 vols.).- John Murray, London, England.

Manheim, F.T., 1967: Evidence for submarine discharge of water on the Atlantic continental slope of the southern United States, and suggestions for further search.- Transactions of The New York Academy of Sciences, Series 2, 29, 839-853.

Manheim, F.T. \& C.K. Paull, 1981: Patterns of ground water salinity changes in a deep continental-oceanic transect off the southeastern Atlantic coast of the USA.- Journal of Hydrology, 54, 95-105.

Mariolakos, I.D. \& D.I. Mariolakos, 2004: The Argon Field in Arcadia, the sinkhole of Nestani village, god Poseidon and the submarine Dini Springs in the Argolic Gulf (Peloponnisos, Greece): a geomythological approach of the Poseidon's birth.- In:Tenth International Congress of the Geological Society of Greece, $15^{\text {th }}-17^{\text {th }}$ April 2004, Thessaloniki, Greece. Bulletin of the Geological Society of Greece, 36, 1146-1153. 
Meisler, H., Leahy, P.P. \& L.L. Knobel, 1984: Effect of eustatic sea-level changes on saltwater-freshwater relations in North Atlantic coastal plain.- U.S. Geological Survey Water Supply Paper, 2255, 1-26.

Nace, R.L., 1974: Pierre Perrault: The man and his contribution to modern hydrology.- Journal of the American Water Resources Association, 10, 633-647.

Pausanias, c. 175 AD: Description of Greece.- Jones, W.H.S. (transl.), 1918 et seq., Harvard University Press, Loeb Classical Library (4 vols.), Cambridge, Massachusetts. [Online] Available from: http:// www.library.theoi.com [Accessed 7th September 2009].

Perrault, P., 1674: On the Origin of Springs (De l'origine des Fontaines).- LaRocque, A., (transl.), 1967, Hafner Publishing Company, pp. 213, New York.

Spechler, R.M. \& W.L. Wilson, 1997: Stratigraphy and hydrogeology of a submarine collapse sinkhole on the continental shelf, northeastern Florida.- In: Beck, B.F. \& J.B. Stephenson (eds.) The Engineering Geology and Hydrogeology of Karst Terranes. Balkema, pp. 61-67, Rotterdam, Netherlands.

Strabo, c. 15 AD: Geography.- Jones, H.L. (transl.) 1924, Harvard University Press, Loeb Classical Library, pp. 408, Vol. 3 (Books 6-7), Cambridge, Massachusetts.
Surić, M., 2002: Submarine karst of Croatia-evidence of former lower sea levels.- Acta Carsologica, 31, 3, 89-98.

Swarzenski, P.W., Reich, C.D., Spechler, R.M., Kindinger, J.L. \& W.S. Moore, 2001: Using multiple geochemical tracers to characterize the hydrogeology of the submarine spring off Crescent Beach, Florida.Chemical Geology, 179, 187-202.

Taniguchi, M., Burnett, W.C., Cable, J.E. \& J.V. Turner, 2002: Investigation of submarine groundwater discharge.- Hydrological Processes, 16, 2115-2129.

Vitaliano, D.B., 1968: Geomythology: the impact of geologic events on history and legend, with special reference to Atlantis.- Journal of the Folklore Institute, $5,5-30$.

Vitaliano, D.B., 1973: Legends of the Earth: their Geologic Origins.- Indiana University Press, pp. 318, Bloomington.

Zötl, J.G., 1989: Bibliography of the history of karst research.- In: LaMoreaux, P.E. (ed.), International Association of Hydrogeologists, Hydrology of limestone terranes, annotated bibliography of carbonate rocks, volume 4. Verlag Heinz Heise, pp. 267, Hannover, West Germany. 